\title{
150. Biosynthesis of Heme Proteins in Embryonic and Early Fetal Life
}

\author{
By Yukio Yasukochi, Hiroshi Nakajima, \\ and Toshiyuki YANASE \\ Department of Clinical Genetics, Tokyo Medical \\ and Dental University, Tokyo \\ (Comm. by Tanemoto Furuhata, M.J.A., June 13, 1966)
}

Recently several investigators have suggested the existence of a "third normal human hemoglobin", a distinctive hemoglobin which precedes the formation of fetal hemoglobin during intra-uterine development. The first suggestion of this came from the work of Drescher and Künzer, ${ }^{1)}$ who reported a hemoglobin with intermediate alkali resistance between $\mathrm{Hb}-\mathrm{A}$ and $\mathrm{Hb}-\mathrm{F}$ in human fetuses at 7 to 12 weeks gestation. This observation was later confirmed by Butler et $a ._{.}{ }^{2)}$ Halbrecht et $a l_{.}{ }^{3), 4)}$ stated that one component of hemolysates from fetuses aged 12 to 20 weeks moved more slowly than those from full-term newborns on paper electrophoresis, in barbiturate buffer at $\mathrm{pH}$ 8.6. This component was named "embryonic" hemoglobin. Matsuda et $a l .,{ }^{5)}$ on the other hand, failed to identify any hemoglobin different from $\mathrm{Hb}-\mathrm{F}$ in fetuses at 7 to 30 weeks gestation.

Huehns $e t a l .{ }^{6)}$ presented an evidence for two previously undescribed hemoglobins, called $\mathrm{Hb}$-Gower 1 and 2, in human fetuses smaller than $85 \mathrm{~mm}$ crown-rump (C.R.). These hemoglobins moved more slowly than $\mathrm{Hb}-\mathrm{C}$ and $\mathrm{Hb}-\mathrm{G} / \mathrm{C}$ respectively on starch gel electrophoresis, using a Tris-citrate/borate discontinuous buffer system. Further, they stated that, on the basis of hybridization experiments, Hb-Gower 1 consisted of four polypeptide chains, with the $\varepsilon$-chain alone being different from

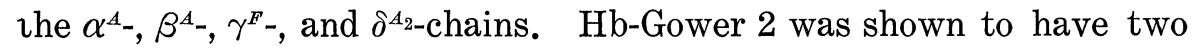
$\alpha$-chains and two $\varepsilon$-chains.

The present paper is concerned with the detection of this new hemoglobin component, which may be synthesized before $\mathrm{Hb}-\mathrm{F}$, and with the evaluation of the phase of its switch-over to later hemoglobins.

Materials and Methods. Blood specimens were obtained from artificially aborted fetuses of 7 to 15 weeks gestation. Hemolysates were separately prepared from the umbilical cord, fetus, and placenta. The fetus and placenta were dissected in 0.9 per cent sodium chloride solution and the red cells were separated by filtration through glass wool. The red cells from the umbilical cord were obtained by wringing or filtration. The isolation of hemoglobin was performed according to Singer et $a l_{.9}{ }^{9}$ 
Hemolysates were prepared within 5 hours after removal of the fetus, and were subjected to starch gel electrophoresis within 45 hours. Starch gel electrophoresis was carried out in a Tris-EDTA-borate continuous buffer system at $\mathrm{pH} 8.6$, or a Tris-EDTA-borate/borate discontinuous system at $\mathrm{pH}$ 8.6. After electrophoresis, the gel was stained with benzidine chloride ${ }^{10)}$ or Amido-Black $10 \mathrm{~B}$. All of the procedures were performed at $0^{\circ}$ to $6^{\circ}$.

The fetal age estimate was based on the menstrual history of the mother and the measurement of the crown-rump of the fetuses when observed intact. The value arrived at by these two methods agreed fairly well. A part of the specimen, which was stained with Giemsa solution before being hemolyzed, was microscopically examined to evaluate the degree of contamination of cells other than blood corpuscles.

Results and Discussion. As shown in Fig. 1, a sample was contaminated by deeply chromatin-staining cells. However, the proportion of contamination remained approximately 10 per cent as judged on blood film. In addition, the gel stained with Amido-Black $10 \mathrm{~B}$ (Fig. 2) showed no band other than protein band usually indicated as unknown protein in normal human hemolysates. ${ }^{11,12)}$ Contamination by maternal blood corpuscles could not be completely eliminated.

1. On the existence of the embryonic hemoglobin. Blood specimens from 41 fetuses at 7 to 14 weeks gestation and from the umbilical cord of 12 fetuses at 9 to 15 weeks gestation, were studied.

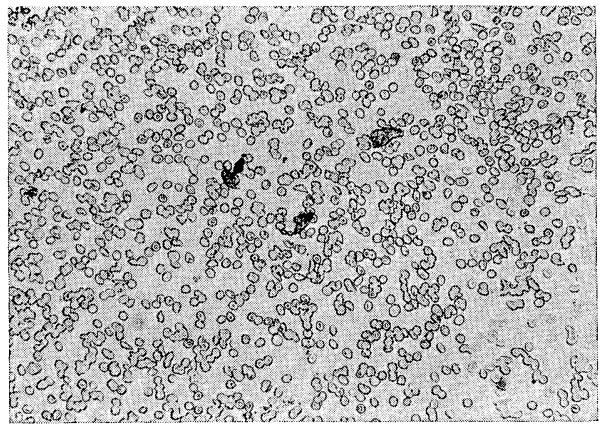

Fig. 1. Peripheral blood corpuscles from an early fetus (a test for contamination from other cells than blood corpuscles). Giemsa staining, Magnif. $\times 180$.

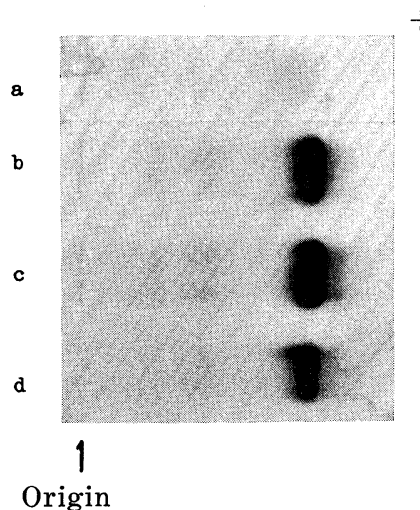

Fig. 2. Starch gel electrophoresis of samples from fetal body, placenta, and umbilical cord.

a: umbilical cord blood (a fetus aged 9 weeks)

b: Fetal body blood (a fetus aged 9 weeks)

c: Placental blood (a fetus aged 9 weeks)

$d:$ Placental blood (a fetus aged 12 weeks) 


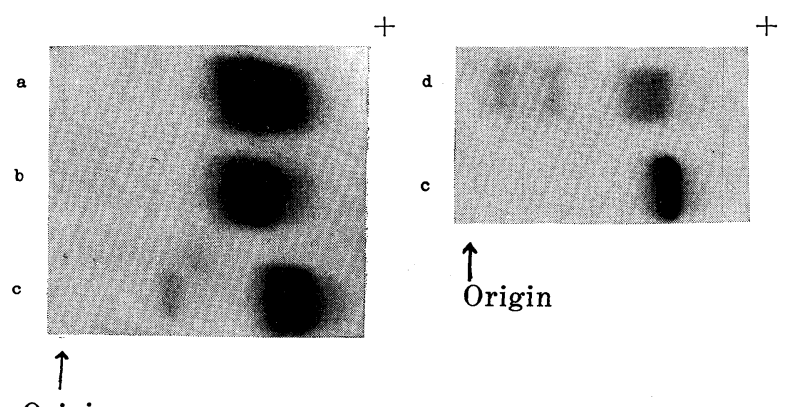

Origin

Fig. 3. Starch gel electrophoresis in a Tris-EDTA-borate buffer system.

a: Umbilical cord blood (a full-term newborn)

b: Umbilical cord blood (a fetus aged 13 weeks)

c: Normal adult blood d: Fetal body blood (a fetus aged 11 weeks)

Table I. Embryonic hemoglobins observed in hemolysates from the body of fetuses at various embryonic stages

\begin{tabular}{c|rrrr|rrrr}
\hline $\begin{array}{c}\text { Fetal age } \\
\text { (menstrual) } \\
\text { Weeks of age }\end{array}$ & + & \multicolumn{2}{|c|}{$\begin{array}{c}\text { Hb-Gower } 1 \\
\pm\end{array}$} & & & \multicolumn{4}{|c}{ Hb-Gower 2} \\
\hline 7 & 2 & & & 2 & 2 & & & 2 \\
8 & 7 & 1 & & 8 & 7 & 1 & & 8 \\
9 & 5 & 2 & 2 & 9 & 6 & 1 & 2 & 9 \\
10 & 3 & & & 3 & 3 & & & 3 \\
11 & 3 & & 3 & 6 & 3 & & 3 & 6 \\
12 & 2 & & 6 & 8 & 1 & & 7 & 8 \\
13 & & & 1 & 1 & & & 1 & 1 \\
14 & & & 4 & 4 & & & 4 & 4 \\
Total & 22 & 3 & 16 & 41 & 22 & 2 & 17 & 41 \\
\hline
\end{tabular}

Table II. Embryonic hemoglobins observed in umbilical cord bloods

\begin{tabular}{|c|c|c|c|c|c|c|c|c|}
\hline \multirow{2}{*}{$\begin{array}{c}\begin{array}{c}\text { Fetal age } \\
\text { (menstrual) } \\
\text { Weeks of age }\end{array} \\
9\end{array}$} & + & \multicolumn{2}{|c|}{$\begin{array}{c}\text { Hb-Gower } 1 \\
\pm\end{array}$} & Sum & \multicolumn{3}{|c|}{ Hb-Gower 2} & Sum \\
\hline & 1 & & & 1 & 1 & & & 1 \\
\hline 10 & & & & & & & & \\
\hline 11 & 1 & & 2 & 3 & 1 & & 2 & 3 \\
\hline 12 & & 2 & 2 & 4 & & 2 & 2 & 4 \\
\hline 13 & 1 & & & 1 & 1 & & & 1 \\
\hline 14 & & & 2 & 2 & & & 2 & 2 \\
\hline 15 & & & 1 & 1 & & & 1 & 1 \\
\hline Total & 3 & 2 & 7 & 12 & 3 & 2 & 7 & 12 \\
\hline
\end{tabular}

Two benzidine-positive bands were observed in fetuses before 12 weeks gestation, and in the umbilical cords before 13 weeks gestation. These bands are not recognizable in the hemoglobins of newborn infants or adults. On starch gel electrophoresis, one of the bands moved a little 
more slowly than $\mathrm{Hb}-\mathrm{A}_{2}$, and another showed nearly one third of the mobility of $\mathrm{Hb}-\mathrm{A}_{2}$ (Fig. 3.). The former apparently corresponds to Hb-Gower 1 and the latter to Hb-Gower 2, as defined by Huehns. ${ }^{6}$ As shown in Tables I and II, these components were observed at a high rate in younger fetuses and were never observed in fetuses after 13 to 14 weeks gestation. Because of the possibility of hemoglobin destruction, the combination of heme with non-heme protein was studied. Fig. 4 gives electrophoretic patterns stained together with benzidine and Amido-Black $10 \mathrm{~B}$, in which Hb-Gower 1 and 2 were clearly distinguished from the unknown protein observed in normal human hemolysates. ${ }^{11,12)}$ This rules against the possibility that these components are artifacts or variants of fetal hemoglobin.

2. The phase of disappearance of hemoglobins Gower 1 and 2. These hemoglobins were never detected in fetuses after 13 to 14 weeks gestation. The present observation shows that these hemoglobins disappear by approximately 13 weeks gestation and may switch over to another component at a later stage. The fetal period of disappearance observed in this study seemed to be slightly earlier than that reported by Huehns et $a .^{7)}$

3. A new benzidine-positive band, intermediate to $\mathrm{Hb}$-Gower 1 and 2. In some embryos of 7 to 9 weeks gestation, three benzidinepositive bands, moving slower than $\mathrm{Hb}-\mathrm{A}_{2}$, were observed on starch gel electrophoresis (Fig. 5). Two of them, the fastest and the slowest ones, correspond to Hb-Gower 1 and 2, respectively. The third one, with intermediate mobility, may be a new hemoglobin. It is not

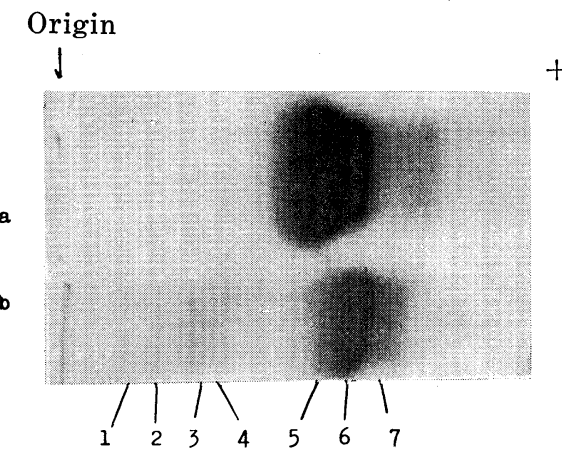

Fig. 4. Known and unknown heme proteins on starch gel electrophoresis. Staining: Benzidine and Amido-Black $10 \mathrm{~B}$.

a: Umbilical cord blood from a fullterm newborn

b: Placental blood from a fetus aged 12 weeks

1: Hb-Gower 2, 2: non-heme protein

3: Hb-Gower 1, 4: Hb-A , 5: Hb-F,

6: $\mathrm{Hb}-\mathrm{A}, 7: \mathrm{Hb}-\mathrm{A}_{3}$

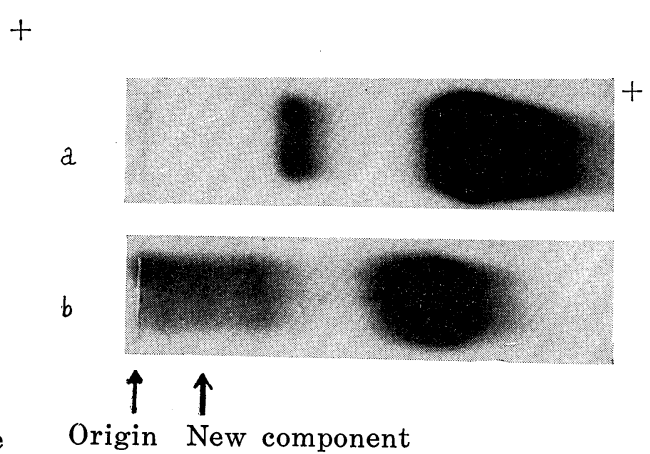

Fig. 5. A new component observed in a fetsus aged 8 weeks

a: Normal adult

b: Fetus in subject 
Table III. Number of samples with embryonic hemoglobins in which a new component was identified

\begin{tabular}{c|cccc}
\hline $\begin{array}{c}\text { Fetal age } \\
\text { (Menstrual) } \\
\text { Weeks of age }\end{array}$ & + & \multicolumn{4}{c}{ New component } \\
\pm & 1 & - & Sum \\
\hline 7 & & & 5 & 2 \\
8 & 2 & & 3 & 7 \\
9 & 3 & & 3 & 3 \\
10 & & & 4 & 4 \\
11 & & & 16 & 23 \\
Total & 5 & 2 & & \\
\hline
\end{tabular}

+ : Clearly recognizable on stained starch gel

\pm : Significantly but unclearly recognizable

surprising that there is a different hemoglobin in the embryo before 9 weeks gestation, because the youngest embryo ( $25 \mathrm{~mm}$ C.R.) which Huehns et $a l{ }^{8}{ }^{8}$ studied corresponds approximately to an embryo of 10 weeks gestation. As shown in Table III, a new component was detected in less than 50 per cent of embryos aged 7 to 9 weeks in which the known hemoglobins were detectable. However, this new component was not detected after 10 weeks gestation. This may indicate that the component disappears at about 10 weeks gestation. On the other hand, the low incidence (less than 50 per cent) suggests that one ought not to exclude the possibility of artifact. Further investigations of the possible biological significance of the new component are under way.

Summary. 41 samples of the fetuses aged 7 to 14 weeks and 12 samples of the umbilical cord from fetuses aged 9 to 15 weeks were studied to ascertain the early hemoglobin.

(1) Heme proteins were determined in the fetuses before 12 weeks gestation and in umbilical cord before 13 weeks gestation. These corresponded to Hb-Gower 1 and 2, as defined by Huehns. Subsequent physico-chemical studies have revealed that these are produced during the early embryonic period, and switched over to other components at later stages, at approximately 12 weeks gestation.

(2) In less than 50 per cent of embryos aged 7 to 9 weeks, a new component, intermediate between $\mathrm{Hb}$-Gower 1 and 2, was detected on starch gel electrophoresis, which was identified to be a previously undefined hemoglobin.

Acknowle dgements. The authors are indebted to Drs. Y. Takayama, T. Narikawa, and N. Chiwata for their kind arrangements for the specimens, and to Dr. A. D. Bloom of Hiroshima ABCC for his careful reading of this paper.

This study was supported in part by a Grant from the Tôyô Rayon Foundation for the Promotion of Science and Technology. 


\section{Refèrènces}

1) Drescher, Ḧ, and Künzer, W.: Klin. Wochschr., 32, 92 (1954).

2) Butler, E. A., Flynn, F. V., and Huehns, E. R.: Clin. Chim. Acta, 5, 571 (1960).

3) Halbrecht, I., and Klibanski, C: Nature, 178, 794 (1956).

4) Halbrecht, I., Klibanski, C., Brzoza, H., and Lahav, M.: Amer. J. Clin. Path., 29, 340 (1958).

5) Matsuda, G., Schroeder, W. A., Jones, R. T., and Weliky, N.: Blood, 16, 984 (1960).

6) Huehns, E. R., Flynn, F. V., Butler, E. A., and Beaven, G. H.: Nature, 189, 496 (1961).

7) Huehns, E. R., Dance, N., Beaven, G. H., Kell, J. V., Hecht, F., and Motulsky, A. G.: Nature, 201, 1095 (1964).

8) Huehns, E. R., Dance, N., Beaven, G. H., Hecht, F., and Motulsky, A. G.: Symposia on Quantitative Biology, 29, 327 (1964).

9) Masri, M. S., Josephson, A. M., and Singer, K.: Blood, 13, 531 (1958).

10) Connel, G. E., and Smithies, O.: Biochem. J., 72, 115 (1959).

11) Kunkel, H. G., Ceppellini, R., Muller-Eberhard, U., and Wolf, J.: J. Clin. Invest., 36, 1615 (1957).

12) Graham, J. L., and Grunbaum, B. W.: Amer. J. Clin. Path., 39, 567 (1963). 